\title{
Kinerja Pembiayaan UMKM Terhadap Profitabilitas Bank Umum Syariah di Indonesia
}

\author{
The performance of MSME Financing on the profitability of Islamic commercial bank \\ in Indonesia
}

\section{Marwah Nur Al-Zauqi}

Program Studi D4 Keuangan Syariah, Politeknik Negeri Bandung

Email: marwahzauqi@gmail.com

\section{Iwan Setiawan}

Jurusan Akuntansi, Politeknik Negeri Bandung

Email: iwan.setiawan@polban.ac.id

\begin{abstract}
This study aims to determine how MSME financing and Capital Adequacy affect the profits of Islamic commercial banks. This study uses a quantitative approach that analyze secondary data from statistic of Islamic Bank in Indonesia period 2016-2019. The analysis used multiple linear regression analysis methods. Data processing uses eviews program. The results of this study indicate that MSME financing has a significant positive effect on Return on Asset. Capital Adequacy Ratio has a significant positive effect on Return on Asset. MSME financing and Capital Adequacy Ratio has a simultant effect to Return on Asset. The results of this study are expected to be a material consideration for Islamic commercial banks in providing MSME financing and maintaining capital adequacy.
\end{abstract}

Keywords: MSME Financing, Capital Adequacy, Profitability

\section{Pendahuluan}

Saat ini, Usaha Mikro, Kecil, dan Menengah (UMKM) adalah bagian amat penting bagi ekonomi Indonesia. Hal in dikarenakan 98,7\% usaha di Indonesia adalah UMKM, yang menampung 89,17\% tenaga kerja domestik dan memberikan kontribusi sebesar 36,82\% terhadap PDB Indonesia (UMKM Bisa Jadi Sumber Pertumbuhan 7 Persen, 2019). Menurut (Kara, 2013), UMKM memiliki daya adaptasi yang tinggi serta memiliki kemampuan untuk bertahan dalam kondisi krisis ekonomi. Namun UMKM memiliki persoalan yang dapat menghambat perkembangannya. Persoalan yang dimiliki UMKM antara lain terbatasnya modal kerja, kualitas SDM yang rendah, kualitas produk serta prodiktivitas yang rendah, dan terbatasnya kemampuan ilmu pengetahuan dan teknologi (Lubis \& Junaidi, 2016).

Peran penting ditunjukkan oleh Bank Umum Syariah dalam memberikan kemudahan bagi pengusaha yang bergerak pada sektor riil untuk memperbaiki perekonomian di ndonesia. Bank Umum Syariah dibutuhkan sebagai mitra usaha yang dapat menyalurkan pembiayaan dengan skema syariah. Skema pembiayaan dengan akad syariah yang diberikan oleh Bank Umum Syariah adalah musyarakah, mudharabah, murabahah, jarah, qard dan stishna' (Ridwan, 2016). Bank Umum Syariah dapat berperan sebagai pemilik modal (Shabibul maal) atau mitra dan pelaku UMKM berperan sebagai pengelola usaha (mudharib). 


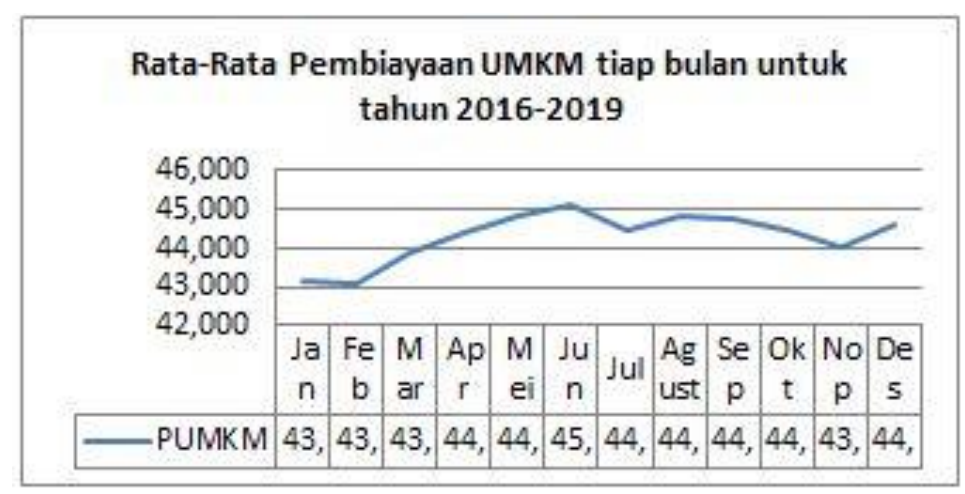

Gambar 1 Rata-Rata Pembiayaan UMKM tiap bulan untuk tahun 2016-2019 oleh BUS di Indonesia (dalam miliar rupiah)

Sumber: (Otoritas Jasa Keuangan) diolah

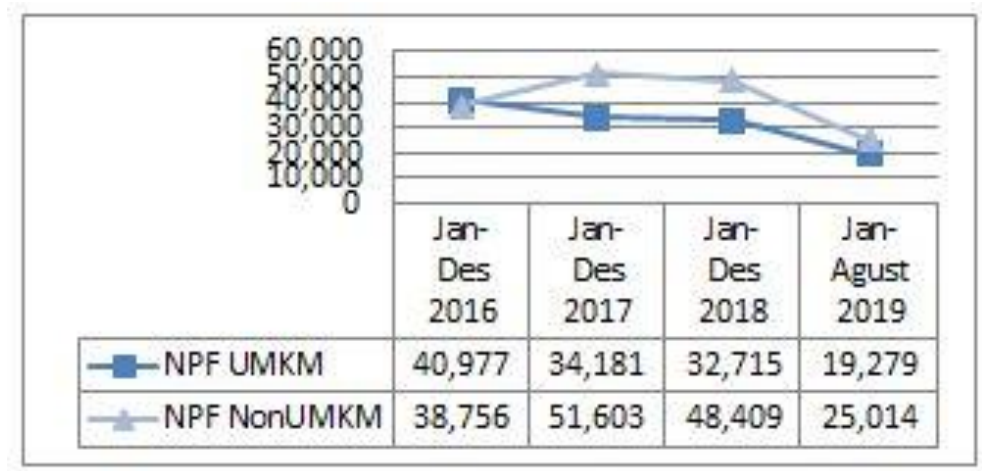

Gambar 2 Non Performing Financing Bank Umum Syariah (dalam miliar rupiah)

Sumber: (Otoritas Jasa Keuangan) diolah

Dilihat dari Gambar 1, rata-rata pembiayaan UMKM yang diberikan Bank Umum Syariah untuk tiap bulannya tahun 2016 hingga 2019 mengalami fluktuasi namun memiliki kecenderungan yang meningkat tiap bulannya. Puncak kenaikan rata-rata pembiayaan UMKM ini terjadi pada bulan Juli. Dilihat dari Gambar 2, tingkat NPF pembiayaan UMKM cenderung lebih kecil daripada tingkat NPF pembiayaan non UMKM. Hal ini berarti pembiayaan yang disalurkan kepada UMKM memiliki risiko tidak tertagihnya pembiayaan yang lebih kecil dari pembiayaan yang disalurkan kepada non UMKM. Meskipun tingkat NPF pembiayaan non UMKM menurun tiap tahunnya, berdasarkan data dari Otoritas Jasa Keuangan, jumlah pembiayaan yang diberikan kepada UMKM jauh lebih kecil apabila dibandingkan dengan pembiayaan yang disalurkan kepada non UMKM. Menurut Kepala Grup Inovasi Keuangan Digital Dan Pengembangan Keuangan Mikro Otoritas Jasa Keuangan, 70\% UMKM di Indonesia masih belum memperoleh akses pembiayaan (Masalah UMKM di RI: Minim Melek Teknologi hingga Sulit Akses Modal).

Risiko tidak tertagihnya pembiayaan akan berdampak pada Bank Umum Syariah dalam mencapai kebutuhan modal. Kecukupan modal minimal Bank Umum Syariah dibutuhkan untuk menunjang aktiva beresiko seperti pembiayaan yang diberikan kepada nasabah. Kecukupan modal dapat dilihat menggunakan Capital Adequacy Ratio, yaitu perbandingan yang menunjukkan penyediaan modal minimum bank yang dilandaskan pada risiko aktiva. Pengelolaan transaksi 
keuangan tentunya perlu diperhatikan dan dilakukan dengan seimbang antara aset dengan liabilitas sehingga dapat dihasilkannya profitabilitas yang maksimal bagi Bank Umum Syariah.

Profitabilitas Bank Umum Syariah perlu diperhatikan juga dipertahankan demi kelangsungan kinerja perbankan syariah. Pembiayaan UMKM dan kecukupan modal yang dilakukan pada UMKM berpotensi untuk memberikan profitabilitas sekaligus membantu pertumbuhan ekonomi di Indonesia.

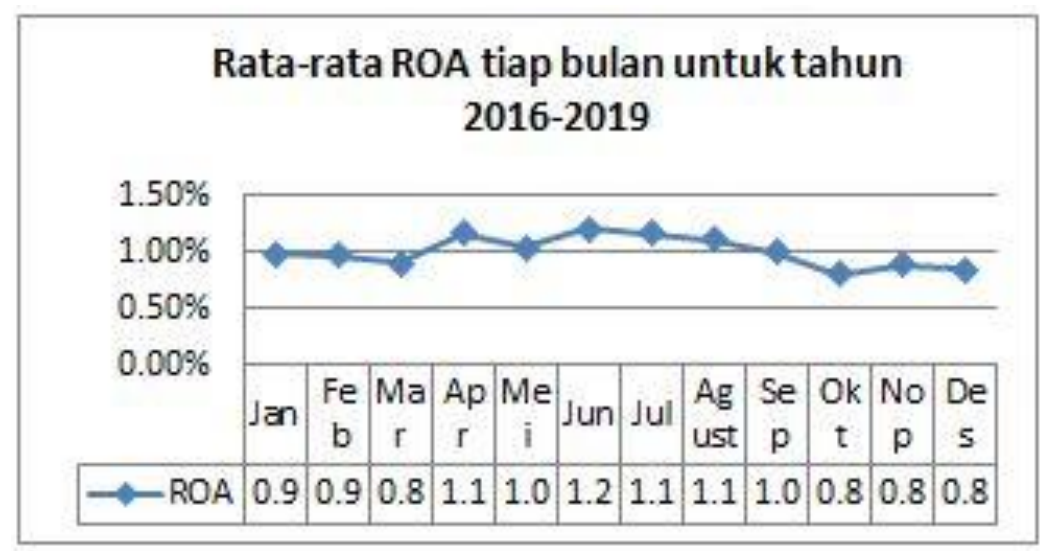

Gambar 3 Rata-Rata ROA tiap bulan untuk tahun 2016-2019 BUS di Indonesia

Sumber: (Otoritas Jasa Keuangan) diolah.

Dilihat pada gambar di atas, kondisi rata-rata ROA yang dimiliki Bank Umum Syariah tiap bulannya tahun 2016 hingga 2019 mengalami fluktuasi namun memiliki kecenderungan yang menurun tiap bulannya. Puncak penurunan rata-rata ROA ini terjadi pada bulan Oktober. ROA merupakan perbandingan yang mengukur kemampuan Bank Umum Syariah dalam menghasilkan profit dari kegiatan operasionalnya. Menurut (Dendawijaya, 2003) besarnya tingkat ROA yang dimiliki Bank Umum Syariah menggambarkan besarnya tingkat profitabilitas yang dihasilkan Bank Umum Syariah. Semakin besar tingkat ROA, semakin besar pula tingkat profitabilitas yang dihasilkan Bank Umum Syariah.

Berdasarkan permasalahan di atas, penyaluran pembiayaan terhadap UMKM oleh Bank Umum Syariah di Indonesia perlu diperhatikan sebab disatu sisi pembiayaan tersebut dapat membantu pertumbuhan ekonomi di Indonesia dan juga menghasilkan profitabilitas bagi Bank Umum Syariah, namun memiliki risiko tidak kembalinya pembiayaan tersebut. Kondisi kecukupan modal minimum Bank Umum Syariah pun perlu diperhatikan guna menanggulangi risiko-risiko yang mungkin akan timbul.

\section{Kajian Pustaka}

Bank Umum Syariah yaitu lembaga keuangan yang menjembatani pihak surplus dana dengan pihak defisit dana, dimana kegiatan usahanya tidak melanggar prinsip-prinsip atau syariat Islam. Bank Umum Syariah melakukan penghimpunan dana serta menyalurkan dana kepada nasabah sesuai dengan syariat Islam. Penghimpunan dana berasal dari sumber modal, dana pihak ketiga, serta pinjaman dari berbagai lembaga keuangan. Dana yang dihimpun kemudian dialokasikan ke berbagai bagian yaitu untuk kepentingan likuiditas dan kegiatan operasional yang bertujuan untuk menghasilkan keuntungan.

Pembiayaan adalah salah satu kegiatan operasional bank syariah yang dilakukan untuk menghasilkan profitabilitas. Pembiayaan bisa diartikan menjadi penyediaan uang atau tagihan yang diberikan kepada pihak lain sesuai dengan kesepakatan antara bank syariah dengan pihak yang 
diberikan pembiayaan, dan pihak tersebut wajib mengembalikan atau membayar kembali pada waktu yang telah disepakati beserta bagi hasil atau imbalan (UU No. 10 tahun 1998). Target penyaluran pembiayaan dapat dikategorikan menjadi dua, yaitu UMKM dan non UMKM. Bank Indonesia sebagai bank sentral telah mengatur penyaluran pembiayaan UMKM dalam (Peraturan Bank Indonesia No. 14/22/2012) dimana bank umum wajib untuk menyalurkan pembiayaan UMKM serendah-rendahnya sebesar $20 \%$ dari total pembiayaan yang diberikan. Pembiayaan UMKM berpotensi untuk memberikan profitabilitas lebih kepada Bank Umum Syariah. Penelitian yang dilakukan (Afkar, 2017) memberikan hasil pembiayaan UMKM berpengaruh positif signifikan kepada kemampuan Bank Umum Syariah dalam menghasilkan profitabilitas. Penelitian lain dilakukan oleh (Faisol, 2017) memberikan hasil bahwasanya pembiayaan yang disalurkan bank syariah memberikan pengaruh positif bagi kinerja dan kesejahteraan UMKM. Pengaruh tersebut berpotensi untuk meningkatkan kinerja bank syariah secara internal.

Kecukupan modal menjadi salah satu faktor yang mampu mempengaruhi kinerja perbankan syariah. Kecukupan modal minimum bisa dilihat melalui Capital Adequacy Ratio (CAR). Capital Adequacy Ratio bisa diartikan sebagai perbandingan yang menunjukkan jumlah modal sendiri milik bank syariah yang diperlukan untuk menaggulangi risiko yang mungkin timbul akibat penanaman aset beresiko. Kewajiban untuk menyediakan modal minimum bank umum telah ditetapkan dalam (POJK Nomor 10/POJK.03/2016) yaitu bank umum wajib untuk menyediakan modal minimum paling rendah sebesar $8 \%$ sesuai dengan profil risiko. (Ma'isyah \& Mawardi, 2015) melakukan penelitian dan hasilnya memperlihatkan bahwasanya kecukupan modal minimum berpengaruh secara signifikan serta positif kepada profitabilitas bank syariah.

Profitabilitas dapat diartikan sebagai landasan dari implikasi antara mutu jasa yang dihasilkan dengan efisiensi operasional suatu bank. Profitabilitas merupakann parameter spesifik yang menunjukkan kinerja suatu bank, dimana profitabilitas adalah sasaran dari manajemen perusahaan dengan mengoptimalkan tingkat return yang diperoleh serta meminimalisir tingkat resiko yang ada (Hijriyani \& Setiawan, 2017). Return on Asset dapat diartikan sebagai salah satu perbandingan yang dipakai untuk menghitung profitabilitas. Return on Asset menggambarkan tingkat keuntungan yang dihasilkan oleh bank syariah berdasarkan kegiatan operasional yang dilakukan. Return on Asset adalah ukuran kemampuan keuangan bank syariah saat menghasilkan keuntungan sebelum pajak yang dihasilkan dari seluruh aktiva (Surat Edaran BI No. 3/30/DPNP tanggal 14 Desember 2001).

Berlandaskan kajian beberapa peneliti yang telah melakukan penelitian dan mengacu pada konsep teori yang ada, maka proses penelitian ini digambarkan melalui kerangka berpikir berikut:

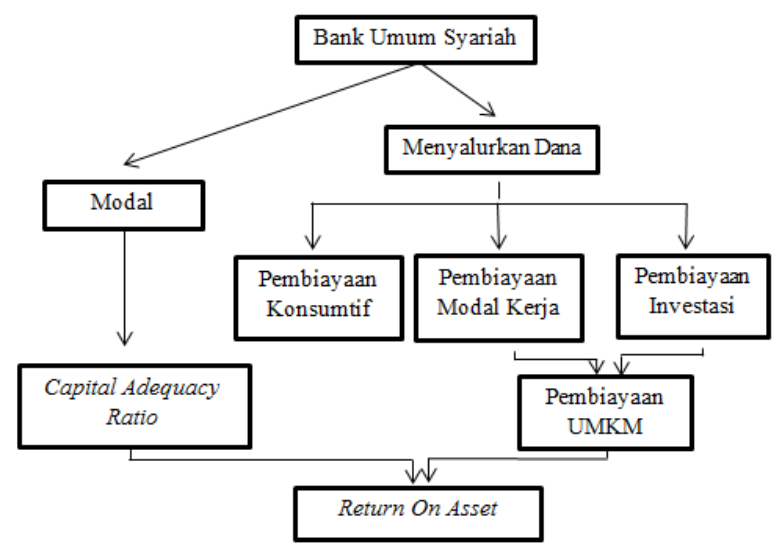

Gambar 4. Kerangka Pemikiran

Sumber: hasil olahan 


\section{Metode Penelitian}

Metode kuantitatif deskriptif dipilih untuk menjadi metode penelitian ini. Penelitian ini memakai data sekunder. Data bersumber dari Statistik Perbankan Syariah periode Januari 2016 Agustus 2019 yang diterbitkan Otoritas Jasa Keuangan. Bank Umum Syariah merupakan objek penelitian. Variabel yang dipakai yaitu Pembiayaan UMKM, Capital Adequacy Ratio, dan Return on Asset Bank Umum Syariah.

Metode analisis yang dipakai yaitu analisis regresi linear berganda, lalu dilakukan uji asumsi klasik serta uji hipotesis. Analisis regresi linear berganda bermaksud untuk meninjau dampak serta kekuatan hubungan antara dua variabel independen terhadap satu variabel dependen (Ghozali \& Ratmono, 2017). Setelah dilakukan uji regresi berganda, dilaksanakan uji asumsi klasik yang bermaksud untuk mendapatkan ketegasan bahwasanya model regresi yang didapatkan mempunyai akurasi dalam estimasi, tidak subjektif, dan konstan (Ghozali, 2011). Asumsi klasik yang dilakukan yaitu Uji Normalitas, Uji Multikolinearitas, Uji Heteroskedastisitas, dan Uji Autokorelasi. Lalu dilaksanakan uji hipotesis, yaitu uji t, uji f, serta uji koefisien determinasi. Uji t (parsial) yang bermaksud untuk meninjau bagaimana dampak dari variable independen kepada variabel dependen dengan berasumsi bahwasanya variabel independen lain bersifat konstan. Uji $f$ (simultan) dilaksanakan untuk meninjau pengaruh dari semua variable independen secara bersamaan kepada variable dependen (Ghozali \& Ratmono, 2017). Koefisien determinasi menunjukkan sejauh apa kekuatan model menjelaskan variasi variable dependen.

\section{Hasil dan Pembahasan}

Berdasarkan hasil olah data yang sudah dilaksanakan, diperoleh model regresi linear berganda di bawah ini:

Tabel 1. Hasil Pengolahan Data

\begin{tabular}{lrlrr}
\hline \hline \multicolumn{1}{c}{ Variable } & Coefficient & Std. Error & t-Statistic & Prob. \\
\hline \hline \multicolumn{1}{c}{ C } & -2.793980 & 0.718235 & -3.890063 & 0.0004 \\
PUMKM & $4.74 \mathrm{E}-05$ & $2.19 \mathrm{E}-05$ & 2.163691 & 0.0364 \\
\multicolumn{1}{c}{ CAR } & 0.097657 & 0.023616 & 4.135254 & 0.0002 \\
\hline \hline R-squared & 0.654803 & Mean dependent var & 1.041364 \\
Adjusted R-squared & 0.637964 & S.D. dependent var & 0.371944 \\
S.E. of regression & 0.223796 & Akaike info criterion & -0.090414 \\
Sum squared resid & 2.053478 & Schwarz criterion & 0.031235 \\
Log likelihood & 4.989109 & Hannan-Quinn criter. & -0.045301 \\
F-statistic & 38.88643 & Durbin-Watson stat & 0.765264 \\
Prob(F-statistic) & 0.000000 & & \\
\hline \hline
\end{tabular}

Sumber: Hasil pengolahan menggunakan eviews

Data yang diolah telah lolos dari uji asumsi klasik yang dilakukan. Hal tersebut mempunyai arti bahwa data baik untuk digunakan dan persamaan regresi yang didapatkan bersifat tidak bias, konstan, dan memiliki akurasi dalam estimasi. Hasil regresi di atas menunjukkan nilai konstanta yang diperoleh sebesar -2,793980. Artinya jika Capital Adequacy Ratio dan Pembiayaan UMKM nilainya 0, akan menghasilkan nilai Return On Asset sebesar -2,793980 \%. nilai variabel PUMKM sebesar 0,0000474. Artinya dengan asumsi nilai Capital Adequacy Ratio tetap, maka peningkatan 1 milyar Pembiayaan UMKM akan meningkatkan nilai Return On Asset sebesar 0,0000474\%. Nilai 
variabel Capital Adequacy Ratio sebesar 0,097657 memiliki arti apabila asumsi nilai Pembiayaan UMKM tetap, maka peningkatan 1\% Capital Adequacy Ratio akan meningkatkan nilai Return On Asset sebesar 0,097657\%.

Nilai probabilitas dari Pembiayaan UMKM dan Capital Adequacy Ratio masing-masing sebesar 0,364 dan 0,0002. Hal tersebut membuktikan bahwasanya tiap-tiap variabel secara parsial memberikan pengaruh signifikan terhadap Return On Asset. Didapatkan Prob(F-statistic) sejumlah 0,0000000. Nilai tersebut menunjukkan bahwa variabel Pembiayaan UMKM dan Capital Adequacy Ratio memberikan pengaruh signifikan secara simultan terhadap Return On Asset. Hasil estimasi menunjukkan nilai koefisien determinan (Adjusted R-squared) sebesar 0,637964. Nilai tersebut memiliki arti bahwasanya secara bersamaan, variabel Pembiayaan UMKM dan Capital Adequacy Ratio dapat mempengaruhi variabel Return On Asset sebesar 63,7964\% sementara sisanya dipengaruhi variabel yang tidak termasuk dalam penelitian.

Pembiiayaan perlu dilakukan Bank Umum Syariah karena pembiayaan termasuk salah satu sumber pendapatan bagi Bank Umum Syariah sehingga Bank Umum Syariah tetap dapat menjalankan kegiatan operasionalnya. Meskipun pembiayaan UMKM telah diatur oleh Bank Indonesia, pemberian pembiayaan oleh Bank Umum Syariah kepada UMKM perlu dicermati agar bisa meminimalisir terjadinya pembiayaan macet. Pengaruh yang diberikan pembiayaan UMKM kepada profitabilitas Bank Umum Syariah pun perlu diperhatikan agar bank syariah dapat mencermati pembiayaan yang akan diberikan.

Hasil dari penelitian ini menunjukkan bahwasanya terdapat pengaruh dari pembiayaan UMKM yang disalurkan Bank Umum Syariah terhadap peningkatan nilai profitabillitas Bank Umum Syariah. Namun ternyata pengaruh yang diberikan Pembiayaan UMKM terhadap profitabilitas Bank Umum Syariah bernilai cukup kecil. Kecilnya nilai pengaruh yang diberikan oleh Pembiayaan UMKM kepada profitabilitas Bank Umum Syariah dapat disebabkan oleh kecilnya nilai pembiayaan yang diberikan kepada UMKM, dibandingkan nilai pembiayaan yang diberikan kepada non UMKM.

Selain berpotensi untuk meningkatkan profitabilitas bagi Bank Umum Syariah, pembiayaan UMKM juga dapat membantu perekonomian ndonesia sebab UMKM adalah bagian yang sangat penting bagi ekonomi Indonesia melihat $98,7 \%$ usaha di Indonesia adalah UMKM. Menurut penelitian yang dilakukan (Setiawan, 2017), pembiayaan yang diberikan perbankan syariah memberikan pengaruh sebesar 1,03\% kepada pertumbuhan ekonomi Indonesia. Dengan penyaluran pembiayaan UMKM oleh Bank Umum Syariah, diharapkan profitabilitas yang dihasilkan Bank Umum Syariah menjadi lebih maksimal, serta pertumbuhan ekonomi di Indonesia akan semakin meningkat.

Capital Adequacy Ratio (CAR) bisa diartikan sebagai perbandingan yang menggambarkan kecukupan modal milik Bank Umum Syariah yang dibutuhkan untuk menanggulangi resiko kerugian yang mungkin muncul akibat penanaman aktiva beresiko. Bank yang sehat merupakan bank yang memiliki tingkat kecukupan modal yang baik. Capital Adequacy Ratio perlu diperhatikan oleh Bank Umum Syariah dalam rangka menjaga kesehatan bank serta kinerja bank dalam memperoleh profitabiilitas.

Hasil penelitian menjelaskan bahwasanya Capital Adequacy Ratio memberikan pengaruh positif signifikan kepada Return On Asset. Hasil yang diperoleh ini membuktikan semakin tinggi kecukupan modal yang dimiliki Bank Umum Syariah, profitabilitas yang akan diterima Bank Umum Syariah pun akan semakin tinggi. Dengan menjaga tingkat kecukupan modalnya, Bank Umum Syariah dapat menanggulangi resiko kerugian yang mungkin muncul akibat penanaman aktiva beresiko sehingga profitabilitas yang dihasilkan Bank Umum Syariah dapat lebih maksimal. 


\section{Penutup}

Berlandaskan rumusan masalah yang telah dipaparkan serta hasil analisis uji regresi linear berganda yang telah dilaksanakan maka diperoleh hasil yang dapat disimpulkan bahwa Pembiayaan UMKM dan Capital Adequacy Ratio bersamaan memberikan pengaruh terhadap Return On Asset Bank Umum Syariah di Indonesia periode Januari 2016 - Agustus 2019.

Pembiayaan UMKM memberikan pengaruh positif signifikan kepada Return On Asset Bank Umum Syariah di Indonesia periode Januari 2016 - Agustus 2019. Pengaruh yang diberikan Pembiayaan UMKM terhadap Return on Asset bernilai cukup kecil. Hal tersebut membuktikan peran Bank Umum Syariah dalam menyalurkan pembiayaan harus lebih mempertimbangkan UMKM sebagai target penyaluran pembiayaannya mengingat kondisi UMKM yang masih kurang mendapatkan bantuan modal serta pembiayaan UMKM sendiri memberikan pengaruh terhadap Bank Umum Syariah dalam memperoleh profitabilitas. Bank Umum Syariah dapat melakukan survey untuk mengetahui kondisi UMKM yang membutuhkan pembiayaan dan secara berkala memantau kondisi pembiayaan UMKM yang diberikan untuk mencegah terjadinya pembiayaan yang macet sehingga profitabilitas yang diperoleh akan lebih maksimal.

Capital Adequacy Ratio memberikan positif signifikan kepada Return On Asset Bank Umum Syariah di Indonesia periode Januari 2016 - Agustus 2019. Capital Adequacy Ratio adalah perbandingan yang menggambarkan kondisi modal minimum bank yang digunakan untuk menutupi resiko yang mungkin muncul akibat penanaman aktiva beresiko. Bank Umum Syariah sudah cukup baik menjaga kondisi modal minimum yang dimilikinya. Kondisi kecukupan modal minimum milik Bank Umum Syariah pun perlu diperhatikan dan tetap dijaga dalam kondisi yang sehat karena kecukupan modal minimum mempengaruhi profitabilitas yang diperoleh Bank Umum Syariah serta menjadi salah satu kriteria tingkat kesehatan Bank Umum Syariah. Kondisi kecukupan modal minimum yang baik dapat membantu Bank Umum Syariah untuk menanggulangi resiko yang mungkin akan timbul akibat penanaman aktiva beresiko serta dapat membuat Bank Umum Syariah berada di tingkat kesehatan yang baik. Dengan tingkat kesehatan yang baik, Bank Umum Syariah dapat lebih banyak menarik masyarakat untuk menjadi nasabahnya sehingga profitabilitas yang dihasilkan dapat lebih maksimal.

\section{Daftar Pustaka}

UMKM Bisa Jadi Sumber Pertumbuban 7 Persen. (2019, May 28). Dipetik January 14, 2020, dari Bisnis.com: https://m/bisnis.com/amp/read/20190528/9/928215/umkm-bisa-jadisumber-pertumbuhan-7-persen

Afkar, T. (2017). Pengaruh pembiayaan UMKM dan Kecukupan modal terhadap kemampuan mendapatkan laba dari aset perbankan syariah di Indonesia. Journal of Islamic Economics.

Bank Indonesia. (t.thn.). Peraturan Bank Indonesia No. 14/22/2012. Dipetik Januari 13, 2020, dari www.ojk.go.id: www.ojk.go.id

Bank Indonesia. (t.thn.). Surat Edaran BI No. 3/30/DPNP tanggal 14 Desember 2001. Dipetik Desember 7, 2019, dari Bank Indonesia: www.bi.go.id

Dendawijaya, L. (2003). Manajemen Perbankan. Jakarta: Ghalia Indonesia.

Faisol. (2017). Islamic Bank Financing and It's Impact on Small Medium Enterprise's Performance. Etikonomi.

Ghozali, I. (2011). Aplikasi Analisis Multivariate dengan Program SPSS. Semarang: Badan Penerbit Universitas Dipenogoro.

Ghozali, I., \& Ratmono, D. (2017). Analisis Multivariat dan Ekonomertika.

Hendry, A. (1999). Perbankan Syariah. Jakarta: Muamalah Institute. 
Hijriyani, N. Z., \& Setiawan. (2017). Analisis Profitabilitas Perbankan Syariah di Indonesia sebagai Dampak dari Efisiensi Operasional. Jurnal Kajian Akuntansi, Vol 1, 199.

Kara, M. (2013). Kontribusi Pembiayaan Perbankan Syariah Terhadap Pengembangan Usaha Mikro, Kecil, dan Menengah.

Lubis, T., \& Junaidi. (2016). Pemanfaatan Teknologi Informasi pada Usaha Mikro, Kecil, dan Menengah di Kota Jambi. Jurnal Perspektif Pembiayaan dan Pembangunan Daerah.

Ma'isyah, R., \& Mawardi, I. (2015). Pengaruh Kecukupan Modal, Fungsi Intermediasi, Efesiensi Operasional, dan Pembiayaan Bermasalah terhadap Profitabilitas. JESTT Vol. 2.

Masalab UMKM di RI: Minim Melek Teknologi hingga Sulit Akses Modal. (t.thn.). Dipetik Januari 29, 2020, dari Detik Finance: finance.detik.com

Otoritas Jasa Keuangan. (2016 - 2019). Statistik Perbankan Syariah. Otoritas Jasa Keuangan.

POJK Nomor 10/POJK.03/2016. (t.thn.). Dipetik Desember 19, 2019, dari Otoritas Jasa Keuangan: www.ojk.go.id

Ridwan, A. A. (2016). Implementasi Akad Muzara'ah pada Bank Syariah. Jurnal Ekonomi Islam.

Setiawan, I. (2017). Peran Perbankan Syariah terhadap Perekonomian di Indonesia (Pendekatan Model VAR/VECM). TEDC Vol. 11 No. 2, Mei 2017, 177.

UU No. 10 tahun 1998. (t.thn.). Dipetik Desember 19, 2019, dari Otoritas Jasa Keuangan: www.ojk.go.id 